\title{
Vascular endothelial growth factor VEGF189 induces human neutrophil chemotaxis in extravascular tissue via an autocrine amplification mechanism
}

\author{
Magali Ancelin ${ }^{1}$, Sylvie Chollet-Martin ${ }^{2}$, Marie Astrid Hervé ${ }^{1}$, Chantal Legrand ${ }^{1}$, \\ Jamel El Benna ${ }^{2}$ and Martine Perrot-Applanat ${ }^{1}$
}

${ }^{1}$ INSERM U553 "Hémostase, Endothélium et Angiogénèse”, Université Paris, Hôpital Saint-Louis, Paris, Cedex France and ${ }^{2}$ Immunology and Haematology Laboratory and INSERM U479, Hôpital X. Bichat, Paris, France

\begin{abstract}
Vascular endothelial growth factor (VEGF) is a potent and specific endothelial cell mitogen involved in normal and pathological angiogenesis. Our group recently reported that, among the several VEGF isoforms, VEGF189 (V189) is selectively induced in decidual endometrial cells during the mid-late phase of the menstrual cycle, together with polymorphonuclear neutrophil (PMN) influx. We thus compared the effects of various VEGF isoforms on PMN migration in vitro, and the mechanisms involved. In transmigration and under-agarose assays, V189 was both chemotactic and chemokinetic for PMN, while VEGF165 (V165) was only chemokinetic. The chemokinetic effect of V189 for PMN was blocked by neutralizing anti-VEGF antibodies, but not by neutralizing anti-KDR antibodies, suggesting that the FIt-1 VEGF receptor that is expressed in PMN mediates these effects. Flow cytometric analysis of several adhesion molecules at the PMN surface showed that all VEGF isoforms slightly upregulated $\beta 1$ - and $\beta 2$-integrins and PECAM, and downregulated L-selectin; all these molecules are activation markers. The involvement of $\beta 1$-integrins was further supported by the ability of blocking antibodies to reduce VEGF-induced PMN migration. As human PMN can secrete several cytokines and growth factors, the selective secretion of VEGF isoforms was also further examined. RT-PCR analysis showed that V165 mRNA was more strongly expressed than V189 mRNA. Conversely, the major protein isoform secreted after optimal PMN degranulation was V189, which was located in both azurophilic and specific granules. PMN-derived VEGF can thus modulate PMN migration. This autocrine amplification mechanism would allow sustained VEGF release to occur at inflammatory sites, and may contribute to both normal and pathological angiogenesis.
\end{abstract}

Laboratory Investigation (2004) 84, 502-512, advance online publication, 16 February 2004; doi:10.1038/labinvest.3700053

Keywords: PMN; chemotaxis; VEGF; isoforms; endometrium

Vascular endothelial growth factor (VEGF) is a potent and specific endothelial cell mitogen that is active in vitro and in vivo. VEGF is a major regulator of developmental, physiological and pathological angiogenesis, in situations such as tumorigenesis, inflammation and wound healing. ${ }^{1-3}$ VEGF is expressed by a wide range of cells, including epithelial and smooth muscle cells, fibroblasts, and leukocytes such as monocytes/macrophages, ${ }^{4}$ T lymphocytes ${ }^{5}$ and polymorphonuclear neutrophils (PMN). ${ }^{6-8}$

Correspondence: M Perrot-Applanat, INSERM U553, 1 Av. Claude Vellefaux, 75475 Paris Cedex 10, France.

E-mail: applanat@chu-stlouis.fr

Received 02 September 2003; revised 04 December 2003; accepted 08 December 2003; published online 16 February 2004
VEGF regulation is complex, as alternative splicing of the human VEGF gene results in at least four isoforms. The two main human isoforms consist of 121 (V121) and 165 (V165) amino acids. VEGF189 (V189) is usually present in low amounts and VEGF206 expression is restricted to embryonic tissues. $^{2}$ The different isoforms appear to have similar structures, and act through two different receptors, namely Flt-1 (or VEGF-R1) and KDR (or Flk-1/KDR or VEGF-R2). ${ }^{9}$ KDR mediates the VEGFdependent mitogenic effect. The VEGF isoforms differ in their heparin-binding properties, membrane association and secretion. ${ }^{10,11}$ V121 does not bind heparin-containing cell-surface proteoglycans, and is soluble. V165 is also soluble, but some V165 remains bound to the cell surface or extracellular 
matrix. The largest isoform, V189, has the highest affinity for heparin and therefore usually remains tightly cell-associated. V189 can function either in its native form (native V189) which binds to Flt-1, or in its cleaved form (clV189) which binds to both Flt1 and KDR, depending on the presence of proteases such as plasmin ${ }^{12}$ and urokinase plasminogen activator. ${ }^{13}$ V165 is the VEGF isoform most extensively studied in in vitro proliferation and migration experiments. The role of V189 is less well known, despite recent studies in tumor models. ${ }^{14,15}$

In the adult, physiological angiogenesis is a prominent feature of the female reproductive tract; especially in the endometrium. ${ }^{16}$ Most studies have shown cycle-dependent changes in VEGF expression in the human endometrium, ${ }^{17-19}$ with a predominance of V121 and V165 mRNA. These changes are detectable in different endometrial cell types. Estradiol increases the expression of VEGF (possibly all isoforms) in epithelial and stromal cells. ${ }^{17,19-21}$ Recently, we reported that progesterone selectively increases V189 expression in perivascular decidual endometrial cells during the mid-late secretory phase of the menstrual cycle, and during early gestation. $^{22}$ We also found that V189 increases capillary permeability, similarly to other VEGF isoforms. ${ }^{22}$ However, the specific kinetic of V189 expression in the endometrium points to other functions investigated in the present study.

Many PMN and monocytes are present in the human endometrium during the premenstrual and menstrual periods, especially in areas of tissue breakdown. ${ }^{23,24}$ PMN are found in only small numbers in intact tissue. ${ }^{23}$ However, PMN in intimate contact with endometrial endothelium have been shown to be a source of intravascular VEGF for vessels undergoing angiogenesis. ${ }^{25} \mathrm{PMN}$ and NK cells (CD $56+)^{26}$ also infiltrate the endometrial stroma during the luteal phase and during pregnancy, under the influence of progesterone. The mechanisms governing selective PMN influx to the human endometrium, and NK cell infiltration, are unknown.

VEGF165 induces monocyte chemotaxis by binding to Flt-1..$^{27,28}$ V165 may also influence adult T-leukemia cell chemotaxis. ${ }^{29}$ Recently, VEGF was reported to modulate transendothelial PMN migration by eliciting the production of chemokines (IL-8 and MCP-1) by brain microvascular endothelial cells. ${ }^{30}$

Here, we show for the first time that VEGF, and especially the native V189 isoform, induces PMN chemotaxis, probably by binding to the Flt-1 receptor. Our results further suggest a role for VEGF-induced PMN migration in angiogenesis and/or inflammation, via an autocrine regulatory loop.

\section{Materials and methods}

\section{Purification of Blood PMN}

Human PMN were purified as previously described. ${ }^{31}$ Briefly, blood from healthy volunteers was collected in sterile lithium heparinate-treated tubes. Leukocytes were rapidly isolated in endotoxin-free conditions by sedimentation on a separating medium containing $9 \%$ Dextran T500 (Pharmacia LKB, Uppsala, Sweden) and 38\% Radioselectan (Schering, Lannoy, France). The leukocyte-rich suspension was further centrifuged on a Ficoll-Plaque density gradient (Pharmacia). The cell pellet was washed with phosphate-buffered saline (PBS), and erythrocytes were removed by hypotonic lysis. For RNA extraction and degranulation experiments, PMN were further purified by 20-min incubation with pan anti-human HLA class II-coated magnetic beads (Dynal, Oslo, Norway) to deplete B lymphocytes, activated $\mathrm{T}$ lymphocytes and monocytes, as previously described. ${ }^{32}$ PMN from the pellet were counted on a Hemalog H1 device (Technicon Instuments Corp, Tarrytown, NY, USA) and adjusted to $10^{5} \mathrm{PMN} / \mathrm{ml}$ in $\mathrm{PBS}$.

\section{Migration and Chemokinesis on Agarose Plates}

Cell migration was analyzed using Nelson et al's ${ }^{33}$ method, modified as described in Vicioso et al. ${ }^{34}$ Agarose (Indubiose A37, BioSepra, VilleneuveLa-Garenne, France) was dissolved in Kreb's buffer $\mathrm{pH} 6.8$ at a concentration of $0.7 \%$, cooled at $56^{\circ} \mathrm{C}$ and then mixed with fetal calf serum (FCS, 10\% final) alone or with the VEGF isoforms (1-100 ng/ $\mathrm{ml}$ ). A pool of human sera (HSA, 10\%) containing C5a fraction was used as a positive control. The agarose was distributed in the plates, allowed to solidify, and stored at $4^{\circ} \mathrm{C}$. Four series of three starshaped wells, $2.4 \mathrm{~mm}$ in diameter, were cut in each plate using a template. The central well of each three-well series received $5 \mu \mathrm{l}$ of suspension containing $10^{5} \mathrm{PMN}$. The dishes were incubated $4-12 \mathrm{~h}$ at $37^{\circ} \mathrm{C}$ in a humidified $5 \% \mathrm{CO}_{2}$ incubator. The 12 -h incubation time showed the longest distance migration and was thus chosen in the experimental procedure.

Migration was quantified immediately by measuring linear distances $(\mathrm{mm})$ with an inverted microscope equipped with an ocular micrometer. These assays were carried out at least four times in triplicate. Migration kinetics were measured in dishes plated with FCS-agarose containing VEGF, human serum or neither. Results were calculated from each triplicate assay and were expressed as the change in the "chemotaxis differential' of cells within VEGF-containing agarose vs control agarose (FCS alone, considered as 100\% migration).

\section{Transmigration Assay}

Transmigration assays were performed using Costar Transwells (polycarbonate filters, $5 \mu \mathrm{m}$ pore size), as previously described for PMN. ${ }^{35,36}$ Membranes were coated with fibronectin $(10 \mu \mathrm{g} / \mathrm{ml}$; Life Technolo-

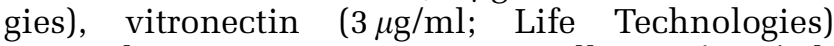
overnight at $4^{\circ} \mathrm{C}$, or type IV collagen $(6 \mu \mathrm{g} / \mathrm{ml}$; 
Collaborative Biomedical Products) for $30 \mathrm{~min}$ at $37^{\circ} \mathrm{C}$, and were then blocked with $1 \mathrm{mg} / \mathrm{ml}$ bovine serum albumin (BSA) for $1 \mathrm{~h}$ at $37^{\circ} \mathrm{C}$. Purified PMN ( $10^{5}$ cells in DMEM, 0.5\% BSA, pH 7.5 buffer) were added to the upper chamber, and VEGF (native and cleaved V189 and V165; 25-50 ng/ml) or IL-8 (a strong physiological chemotactic factor for PMN, $10 \mathrm{ng} / \mathrm{ml}$ ) were added to the bottom chamber. Controls lacked IL-8 and VEGF. After incubation at $37^{\circ} \mathrm{C}$ for $2-4 \mathrm{~h},{ }^{37}$ cells were collected from the lower chamber and counted. In some experiments, VEGF $(25 \mathrm{ng} / \mathrm{ml})$ was preincubated with anti-VEGF neutralizing antibody (clone MAB293, R\&D Systems, Minneapolis, MN, USA; $1 \mu \mathrm{g} / \mathrm{ml}$ ) or anti-KDR neutralizing antibody (clone 2c3, see Brekken et $a l^{38}$ ) for $30 \mathrm{~min}$. In addition, cells were treated with $10 \mu \mathrm{g} / \mathrm{ml}$ of an anti- $\beta 1$-integrin blocking antibody (clone 6S6; Chemicon International).

\section{Adhesion Assay}

In all, 96-well plates were pre-coated as described above. PMN suspensions ( $10^{5}$ cells in DMEM) were added in the presence or absence of VEGF (25$50 \mathrm{ng} / \mathrm{ml})$ or IL-8 $(10 \mathrm{ng} / \mathrm{ml})$ for $30 \mathrm{~min} .{ }^{37}$ Nonadherent cells were removed by two gentle washes with DMEM. Adherent cells were stained with $2 \%$ crystal violet for $5 \mathrm{~min}$ and quantified as previously described. ${ }^{36}$

\section{Expression of Adhesion Molecules on Whole-Blood PMN}

Heparinized whole blood $(1 \mathrm{ml})$ was incubated at $37^{\circ} \mathrm{C}$ for $30 \mathrm{~min}$ with VEGF (cleaved or native V189 and V165, 0.1-250 ng/ml). Control samples were maintained at $4^{\circ} \mathrm{C}$ or incubated at $37^{\circ} \mathrm{C}$ without VEGF. PMN expression of $\beta 2$-integrin, L-selectin, $\beta 1$-integrin and PECAM was then measured as previously described, ${ }^{39}$ after 30 -min incubation at $4^{\circ} \mathrm{C}$ with respectively phycoerythrin-conjugated anti-CD11b (Dako, Glostrup, Denmark), fluoresceinisothiocyanate (FITC) conjugated anti-CD62-L (Immunotech, Marseille, France), FITC-conjugated antiCD29 (Beckman Coulter, FL, USA), or FITC-conjugated anti-CD31 (Dako). Nonspecific binding was determined with irrelevant antibodies of the same isotypes. Erythrocytes were then removed by hypotonic lysis in FACS lysing solution (Becton Dickinson, Immunocytometry Systems, San Jose, CA, USA) and the cell pellet was resuspended in formol $(0.1 \%)$. Flow cytometry was performed using a FACScan apparatus (Becton Dickinson). Fluorescent emission was recorded with a constant photomultiplier gain, and the results were expressed as the median fluorescence intensity (MFI) in a fourdecade logarithmic scale.

\section{Degranulation Experiments}

Highly purified PMN depleted of HLA class IIpositive cells were resuspended in Hank's balanced salt solution (HBSS with $\mathrm{Ca}^{2+} / \mathrm{Mg}^{2+}$; Life Technologies, Cergy-Pontoise, France) and adjusted to $10^{7}$ cells $/ \mathrm{ml}$. To ensure total degranulation, PMN were preincubated at $37^{\circ} \mathrm{C}$ with $5 \mu \mathrm{g} / \mathrm{ml}$ cytochalasin B (Sigma) for $5 \mathrm{~min}$, then with $10^{-6} \mathrm{M} \mathrm{N}$-formylmethionyl-leucyl-phenylalanine (fMLP, Sigma) for $10 \mathrm{~min}$, as previously described..$^{32}$ Unstimulated control PMN were kept at $37^{\circ} \mathrm{C}$ for $20 \mathrm{~min}$ in medium alone. After centrifugation, the cell-free supernatants were stored at $-80^{\circ} \mathrm{C}$ until Western blot analysis.

\section{Subcellular Fractionation}

Azurophilic and specific granules were purified as previously described. ${ }^{32,40}$ Briefly, $10^{8}$ highly purified PMN in $5 \mathrm{ml}$ of ice-cold relaxation buffer $(100 \mathrm{mM}$ $\mathrm{KCl}, 3 \mathrm{mM} \mathrm{NaCl}, 1 \mathrm{mM} \mathrm{Na}_{2} \mathrm{ATP}, 3.5 \mathrm{mM} \mathrm{MgCl}_{2}$, $10 \mathrm{mM}$ PIPES, pH 7.2) supplemented with EGTA and antiproteases were pressurized with $\mathrm{N}_{2}$ for 20 min at 450 psi with constant stirring. The cavitate was then collected dropwise into $1.25 \mathrm{mM}$ EGTA, $\mathrm{pH}$ 7.4. Nuclei and unbroken cells were pelleted by centrifugation of the cavitate for $15 \mathrm{~min}$ at $400 \mathrm{~g}$. The supernatant was decanted, loaded on top of a twolayer Percoll gradient $(1.05 / 1.12 \mathrm{~g} / \mathrm{ml})$ precooled to $4^{\circ} \mathrm{C}$, and centrifuged at $40000 \mathrm{~g}$ for $30 \mathrm{~min}$ at $4^{\circ} \mathrm{C}$. Three fractions were collected: an upper fraction containing secretory vesicles and plasma membranes; an intermediate fraction containing specific and gelatinase granules; and a lower fraction containing azurophilic granules. The purity of specific and azurophilic granules was assessed by ELISA measurement of their respective markers (lactoferrin and myeloperoxidase).

\section{RNA Extraction and Reverse Transcription}

Total RNA was isolated from human neutrophils using TriZol as recommended by the manufacturer. For the reverse transcription step, single-stranded cDNA was synthesized from $1 \mu \mathrm{g}$ of total RNA in the presence of Moloney murine leukemia virus reverse transcriptase and the oligo (dT) primers. ${ }^{19}$ For PCR, oligo primers were chosen from homologous parts of the coding region of the human VEGF receptor genes (Flt-1 and KDR), the VEGF gene, and the housekeeping gene GAPDH. The Flt-1 sense primer was $5^{\prime}$-GTCACAGAAGAGGATGAAGGTGTCTA-3' and the antisense primer was 5'-CACAGTCCGGCACG TAGGTGATT- $3^{\prime}$. The KDR sense primer was $5^{\prime}-$ CAACCTTCTAGGTGCCTGTAC- ${ }^{\prime}{ }^{\prime}$ and the antisense primer was $5^{\prime}$-GGATATTTCGTGCCGCCTGG-3'. The VEGF sense primer was 5'-ACCAARGCCAGC ACATAGGAGAGAT- $3^{\prime}$ and the antisense primer was $5^{\prime}$-CACCGCCTTYGGCCTTGTCACAT-3' ${ }^{\prime}$ Double-stranded cDNAs were synthesized and amplified using 1.25 U Taq polymerase, $10 \mathrm{mM}$ Tris-HCl (pH 9.0), $50 \mathrm{mM} \mathrm{KCl,} 0.1 \%$ Triton (X-100, $0.2 \mathrm{mM}$ $\mathrm{dNTP}$, and $10 \mathrm{pmol}$ of each primer in a final volume 
of $50 \mu \mathrm{l}$. Amplification was carried out in a DNA thermal cycler for 30 cycles at 95, 60 and $72^{\circ} \mathrm{C}$ (for $30 \mathrm{~s}, 1$ and $1 \mathrm{~min}$, respectively) for the Flt-1 and KDR genes, or at 94,56 and $72^{\circ} \mathrm{C}$ for the VEGF gene. RTPCR of the housekeeping gene GAPDH was run for 22 cycles with the sense primer 5'-ATCAC CATCTTCCAGGAGCG- $3^{\prime}$ and the anti-sense primer 5'-CCTGCTTCACCACCTTCTTG-3'. PCR fragments, along with molecular weight standards, were analyzed by $8 \%$ polyacrylamide gel electrophoresis and visualized by ethidium bromide staining.

\section{VEGF Immunoblotting}

Proteins were electrophoresed in $12 \%$ SDS/PAGE gel in reducing conditions, as previously described ${ }^{22}$ and transferred to polyvinylene difluoride membranes (Polyscreen NEN, Life Science Products). An anti-VEGF antibody (A-20, Santa Cruz Biotechnology; $2 \mu \mathrm{g} / \mathrm{ml}$ ), followed by peroxidaseconjugated anti-rabbit IgG (Amersham Life Technologies, 1/2000 dilution), was used to detect VEGF with the enhanced chemiluminescence system (Amersham). In other experiments, the anti-VEGF antibodies were preincubated with recombinant VEGF before probing the membranes. ${ }^{19}$

\section{Immunocytochemistry}

Immunocytochemistry was performed on acetonefixed frozen sections of human endometrial biopsy specimens obtained from cycling women undergoing routine gynecologic investigations, as previously described. ${ }^{19,41}$ Sections were successively incubated with monoclonal mouse anti-CD15 (Becton Dickinson 1/20), FITC-labeled anti-mouse IgG, rabbit anti-VEGF (Santa Cruz Biotechnology, 1/100), biotinylated anti-rabbit IgG and Texas-red-streptavidin (Amersham).

\section{Statistical Analysis}

All results are expressed as means \pm s.e. of the mean (s.e.m.), or as ranges when appropriate. The significance of differences between groups was determined by using Student's $t$-test. $P$-values of $<0.05$ were considered significant.

\section{Results}

\section{VEGF-165 and VEGF-189 Treatment Induces Chemokinesis and Chemotaxis of Human PMN}

Numerous agents, including human complement fraction C5a and IL-8, have been shown to modulate neutrophil migration. The effect of VEGF on human PMN migration was thus compared with that of fraction C5a and IL-8, using two different approaches to test chemokinesis and chemotaxis.
We first used our agarose overlay technique, in which the tested factor (VEGF or C5a fraction contained in human serum) was included in the agarose (see Materials and methods). As shown in Figure 1, the positive control (C5a fraction) increased PMN chemokinesis. Native V189 (1-50 ng/ $\mathrm{ml}$ ) also induced a significant increase in PMN chemokinesis; the effect was concentration-dependent manner, being most potent at $25 \mathrm{ng} / \mathrm{ml}$ $(35 \pm 8 \%)$ (Figure 1). The effect of V165 was significant at $50 \mathrm{ng} / \mathrm{ml}(34 \pm 6 \%$ increase). In contrast, clV189 did not induce PMN chemokinesis at any concentrations.

The effect of VEGF on PMN migration was also tested in a transmigration assay using different adhesion molecules (fibronectin, vitronectin and type IV collagen) to coat the filters. As expected, IL-8 induced a two-fold increase in PMN transmigration (Figure 2); this effect was stronger with fibronectin coating $(114 \pm 7 \%$ increase; Figure 2) than with vitronectin or type IV collagen coating (not shown). Native V189 at 25 and $50 \mathrm{ng} / \mathrm{ml}$ also increased PMN chemotaxis relative to untreated controls; this effect was stronger with fibronectin $(57 \pm 4 \%$ increase, Figure 2$)$ than with vitronectin (not shown). No significant increase in chemotaxis was observed with V165 or clV189 under similar conditions (Figure 2). However, there was a trend towards an increase when these isoforms were used at $50 \mathrm{ng} / \mathrm{ml}$, both on fibronectin (Figure 2) and on type IV collagen (not shown).

VEGF-induced PMN migration was reduced in the presence of an excess of the anti-VEGF neutralizing antibody (clone MAB293), as compared to that

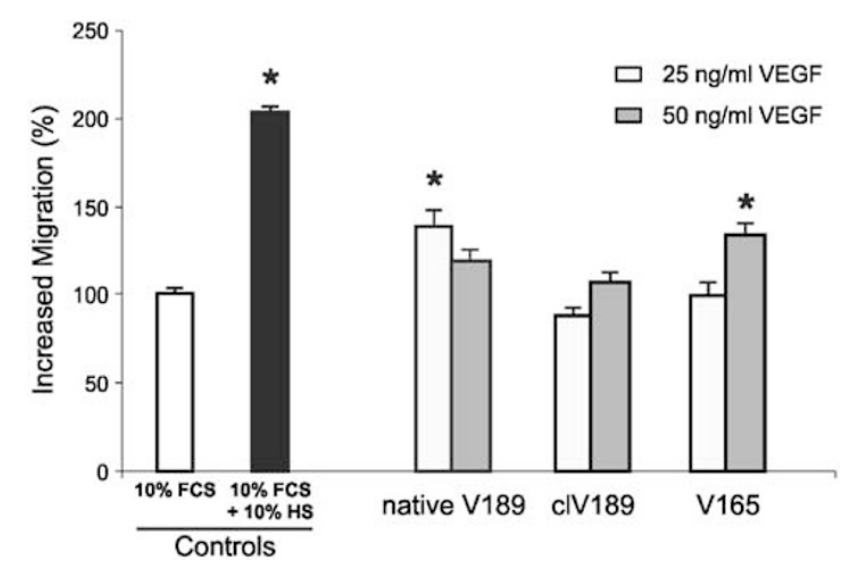

Figure 1 VEGF induces PMN chemokinesis. PMN were incubated with V165 and V189 (native and cleaved fraction), at various concentrations $(1-100 \mathrm{ng} / \mathrm{ml})$, or with $10 \%$ human serum, and migration was assessed after overnight incubation at $37^{\circ} \mathrm{C}$ in an under-agarose assay (see Materials and methods). Differential chemotaxis (in mm) was calculated (see Materials and methods). Control migration (in the presence of FCS) corresponded to $100 \%$. Results are expressed as the percentage difference between VEGFstimulated and -unstimulated cells. Each point represents the mean \pm s.e.m. of the values obtained with samples from five healthy volunteers; and each value is based on triplicate determination of PMN migration $(n=15),{ }^{*} P<0.01$. 
506

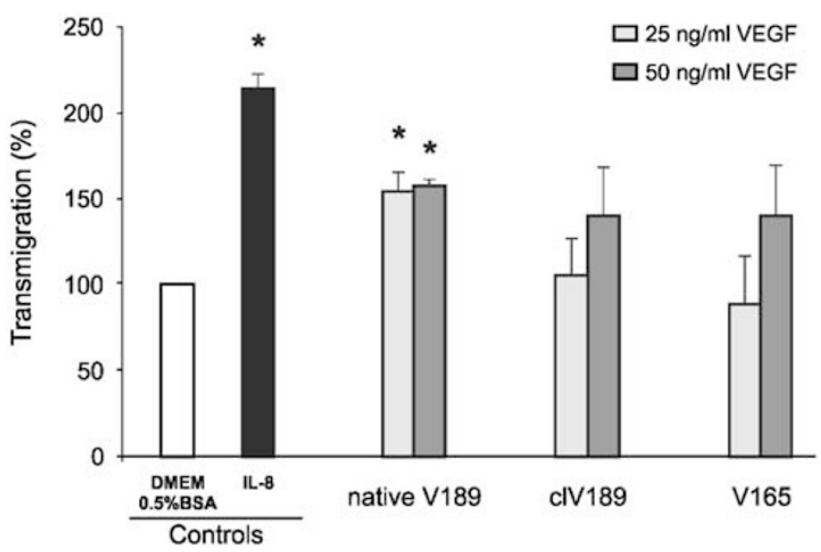

Figure 2 VEGF induces PMN transmigration across fibronectin. PMN were allowed to transmigrate for $4 \mathrm{~h}$ at $37^{\circ} \mathrm{C}$ across Transwell filters ( $5 \mu \mathrm{m}$ pores) coated with $10 \mu \mathrm{g} / \mathrm{ml}$ fibronectin in the presence or absence (control) of VEGF (native and cleaved V189 and V165; $25-50 \mathrm{ng} / \mathrm{ml})$ or IL8 $(10 \mathrm{ng} / \mathrm{ml})$ in the lower chamber. Percentage values represent the mean \pm s.e.m. of at least four separate experiments \pm s.e.m. $(n=12),{ }^{*} P<0.01$.

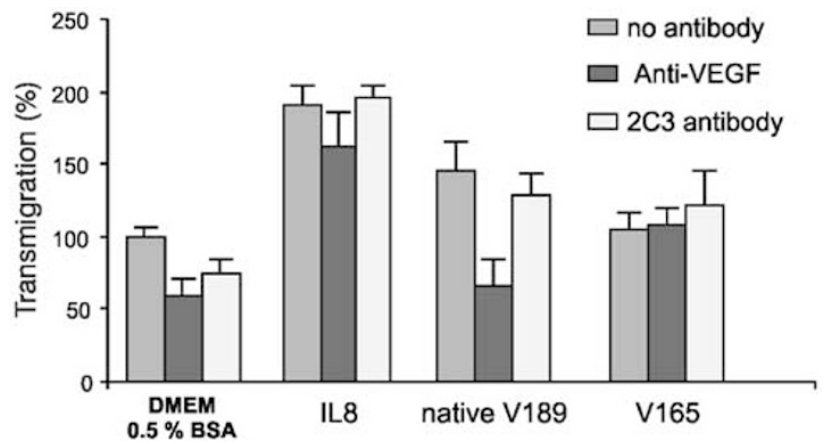

Figure 3 VEGF-induced PMN transmigration is inhibited with anti-VEGF neutralizing antibodies. PMN were allowed to transmigrate for $4 \mathrm{~h}$ at $37^{\circ} \mathrm{C}$ across fibronectin-coated Transwell filters in the presence of native V189 $(25 \mathrm{ng} / \mathrm{ml})$ or IL8 $(10 \mathrm{ng} / \mathrm{ml})$ preincubated or not with a 10-fold excess of anti-VEGF or anti$\mathrm{KDR}^{38}$ neutralizing antibodies. A representative experiment is shown.

observed in the absence of antibody (Figure 3). In contrast, IL-8-induced PMN migration was unaffected after addition of anti-VEGF antibodies. In addition, as the effect on transmigration observed with VEGF could result from PMN adhesion and/or migration on/through fibronectin, we analyzed the effect of VEGF on PMN adhesion to plastic plates. None of the VEGF isoforms increased PMN adhesion to fibronectin (data not shown).

These results showed that VEGF isoforms induced neutrophil chemokinesis, and that native V189 was also chemotactic for these cells.

\section{VEGF-Induced PMN Migration Involves the VEGF Receptor Flt-1}

Previous studies have identified Flt-1 as the functional VEGF receptor on monocytes/macrophages. ${ }^{27,28}$
We thus examined whether functional Flt-1 and Flk$1 /$ KDR were present on the PMN outer membrane. While PMN migration was inhibited by neutralizing anti-VEGF, it was unaffected by the presence of a 100 -fold excess of 2c3, an antibody that blocks VEGF from binding to KDR but not to Flt-1 (Figure 3). In addition, using RT-PCR analysis (Figure 4) we found that highly purified PMN significantly expressed Flt-1 although in lower amounts than endothelial cells; in contrast, little or no Flk-1/KDR expression was detected (Figure 4), a finding that was confirmed by quantitative RT-PCR (Light Cycler, not shown). Immunocytochemistry with an anti-Flt-1 antibody also demonstrated the presence of this receptor on PMN (not shown). Altogether, these data strongly suggest that the effect of VEGF on PMN migration is mediated by the Flt-1 pathway.

\section{VEGF-189 Modulates PMN Expression of Adhesion Molecules}

PMN expression of several adhesion molecules was studied by flow cytometry, both in basal conditions and after incubation with different VEGF isoforms (V165, native and cleaved V189).

As shown in Table 1 a low, but significant, increase $(P<0.05)$ in the expression of $\mathrm{CD} 11 \mathrm{~b}$ (a subunit of $\beta 2$-integrin) by whole-blood PMN was observed with V165 and native V189 at $50-125 \mathrm{ng} / \mathrm{ml}$. CD62L (L-selectin) expression was reduced by V189 (especially by native V189 at $1-10 \mathrm{ng} / \mathrm{ml}, P<0.01)$. CD29 ( $\beta 1$-integrin) expression was significantly increased by all VEGF isoforms

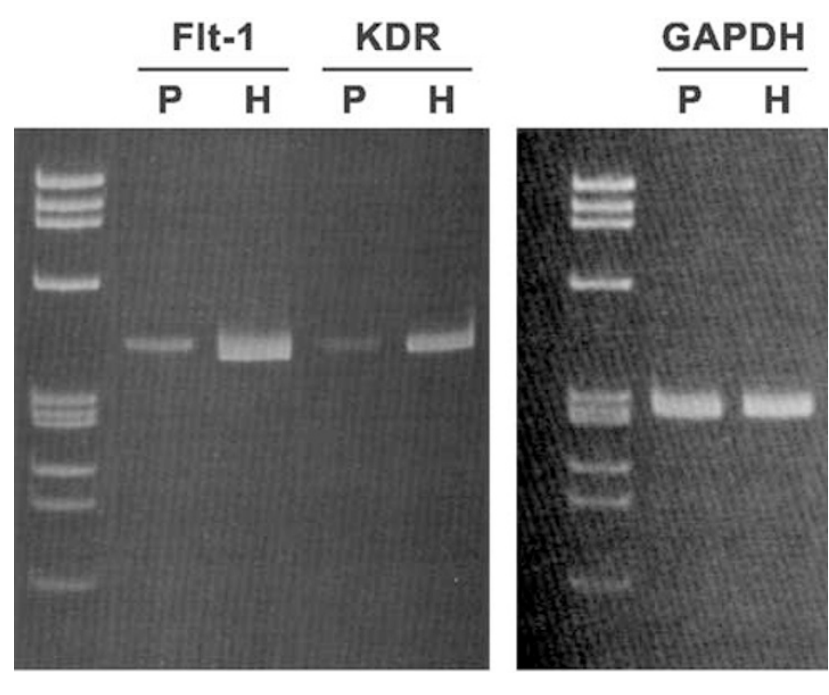

Figure 4 Expression of VEGF receptor Flt-1 transcripts in human PMN. Total RNA was extracted from highly purified human PMN. RNA ( $1 \mu \mathrm{g})$ was reverse transcribed (RT), and aliquots of the RT solution were amplified for 30 cycles using specific oligonucleotides for Flt-1 and KDR. Ethidium bromide-stained gels of Flt-1 and KDR RT-PCR products from human PMN (line P) and HUVEC (endothelial cells, line $\mathrm{H}$ ) are shown. 
Table 1 Effect of VEGF on the expression of adhesion molecules at the PMN surface

\begin{tabular}{lcclc}
\hline Tested molecules & CD11b & CD62L & CD29 & CD31 \\
\hline V165 (ng/ml) & & & & \\
0.1 & $93 \pm 5$ & 104 & $101 \pm 8$ & $103 \pm 5$ \\
1 & $97 \pm 6$ & 96 & $100 \pm 9$ & $104 \pm 5$ \\
10 & $98 \pm 2$ & 104 & $135 \pm 22$ & $110 \pm 7$ \\
50 & $105 \pm 2^{*}$ & 100 & $112 \pm 9$ & $105 \pm 4$ \\
125 & $110 \pm 3^{*}$ & $\mathrm{ND}$ & $112 \pm 3^{*}$ & $103 \pm 2$ \\
250 & $121 \pm 5^{*}$ & 104 & $100 \pm 2$ & $99 \pm 3$ \\
& & & & \\
Native V189 0.1 (ng/ml) & $97 \pm 8$ & $98 \pm 1$ & $101 \pm 12$ & $100 \pm 4$ \\
1 & $96 \pm 2$ & $87 \pm 2^{*}$ & $109 \pm 9$ & $104 \pm 3$ \\
10 & $114 \pm 13$ & $89 \pm 1^{*}$ & $109 \pm 7$ & $107 \pm 1^{*}$ \\
50 & $115 \pm 6^{*}$ & $76 \pm 25$ & $118 \pm 9$ & $109 \pm 4$ \\
125 & $107 \pm 1^{*}$ & $\mathrm{ND}$ & $136 \pm 2^{*}$ & $110 \pm 4$ \\
250 & $91 \pm 15$ & $102 \pm 5$ & $113 \pm 10$ & $105 \pm 6$ \\
& & & & \\
clV189 0.1 (ng/ml) & $96 \pm 3$ & $106 \pm 6$ & $125 \pm 17$ & $106 \pm 3$ \\
1 & $102 \pm 3$ & $98 \pm 1$ & $109 \pm 4$ & $97 \pm 4$ \\
10 & $125 \pm 22$ & $63 \pm 24$ & $115 \pm 1^{*}$ & $102 \pm 3$ \\
50 & $132 \pm 18$ & $95 \pm 8$ & $120 \pm 1^{*}$ & $110 \pm 1^{*}$ \\
125 & $112 \pm 8$ & $\mathrm{ND}$ & $112 \pm 1^{*}$ & $116 \pm 3^{*}$ \\
250 & $95 \pm 12$ & $85 \pm 9$ & $126 \pm 1^{*}$ & $106 \pm 2^{*}$ \\
\end{tabular}

Whole blood was incubated for $30 \mathrm{~min}$ at $37^{\circ} \mathrm{C}$ with $0.1-250 \mathrm{ng} / \mathrm{ml}$ V165 or V189 (native and cleaved fraction). Results are the mean \pm s.e.m. percentage variation of median fluorescence intensity vs controls (incubation with PBS alone, in the absence of VEGF.

$* P<0.05$.

ND: not determined.

used at $125 \mathrm{ng} / \mathrm{ml}$, most markedly by native V189. PECAM-1 (CD31) expression showed little variation, although it tended to increase under VEGF stimulation. These results showed that VEGF induced a moderate increase in the expression of some adhesion molecules (CD11b and CD29) involved in PMN migration. CD29 was the only adhesion molecule whose expression was significantly increased by all VEGF isoforms, the strongest effect being observed with V189.

\section{VEGF-Triggered Migration on Fibronectin is ß1-Integrin Dependent}

As CD29/ $\beta 1$-integrins could be involved in VEGFinduced PMN migration, we then examined the effects of the $\beta 1$-integrin-neutralizing monoclonal antibody 6S6. As shown in Figure 5, V189induced PMN chemotaxis on fibronectin was inhibited by antibody $6 \mathrm{~S} 6 \quad(73 \pm 8 \%$ decrease at $50 \mathrm{ng} / \mathrm{ml}$ V189; $P<0.05$ vs control). Similar inhibition was observed when IL-8 was used as the chemotactic agent $(47 \pm 9 \%$ decrease; $P<0.01$; Figure 5). In contrast, antibody $6 \mathrm{~S} 6$ had no inhibitory effect on V189-induced chemotaxis when vitronectin was used as the coating substance (not shown). These results further indicated that VEGF enhanced PMN migration on fibronectin through a mechanism involving $\beta 1$-integrin upregulation and integrity.

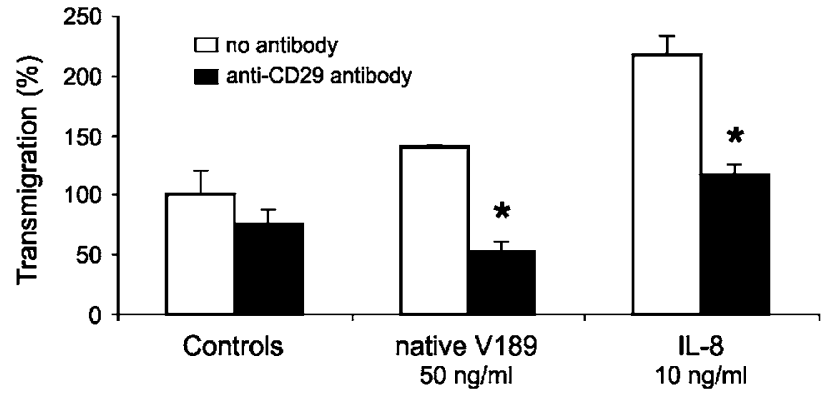

Figure 5 A monoclonal antibody specific for $\beta 1$-integrin inhibits V189-induced PMN transmigration across fibronectin. PMN migration $\left(10^{5} / \mathrm{ml}\right)$ was evaluated on fibronectin-coated Transwell filters as described in Figure 2, in the presence of $50 \mathrm{ng} / \mathrm{ml}$ native V189 or $10 \mathrm{ng} / \mathrm{ml} \mathrm{IL-8} \mathrm{in} \mathrm{the} \mathrm{lower} \mathrm{chamber,} \mathrm{and} \mathrm{in} \mathrm{the} \mathrm{presence}$ or absence of $10 \mu \mathrm{g} / \mathrm{ml}$ anti- $\beta 1$-integrin antibody. ${ }^{36}$ Control, incubation of PMN in the absence of VEGF and IL-8. Isotypematched IgG served as the control mAb, and had no effect (not shown). Data represent means (s.e.m.) of triplicate determinations and are representative of three separate experiments. ${ }^{*} P<0.01$, as compared with cells incubated without anti-CD29 antibody.

\section{Human PMN Express all VEGF Isoforms; VEGF189 is the Main Degranulated Isoform}

Several studies have shown VEGF secretion and VEGF mRNA expression by PMN. Here, we examined the expression and release of individual VEGF isoforms. RT-PCR analysis mainly identified the V121 and V165 mRNAs (Figure 6), while V189 mRNA was only weakly amplified.

The VEGF release was then analyzed after total PMN degranulation induced by cytochalasin and fMLP. As shown in Figure 7a, in Western blot experiments, the main VEGF isoform released by PMN comigrated with recombinant V189 protein (28-30 kDa). This suggested that PMN have an intracellular pool of VEGF, mainly constituted by the V189 isoform. To further localize the intracellular pool of VEGF in human PMN, fractions of azurophilic and specific granules were prepared. As shown in Figure 7b, VEGF was located in both granules, as the 189-, 165- and 121-amino-acid isoforms. VEGF189 was also located in azurophilic granules and, in smaller amounts, in the membrane fraction; no VEGF was detected in the cytosolic fraction.

\section{Human PMN Present in the Human Endometrium During Menstruation Express VEGF}

Several previous studies have reported PMN influx in the human endometrium at the end of the menstrual cycle, ${ }^{23,24}$ together with VEGF increase in the secretory phase, ${ }^{17-19,22}$ suggesting an interplay between VEGF and PMN. ${ }^{25}$ As shown in Figure 8, strong VEGF staining was found on PMN within and migrating from vessels, and in connective tissues. These cells were CD15-positive. The specificity of VEGF staining was demonstrated by the loss of staining after preabsorption of the primary antibody with rhVEGF (not shown). 


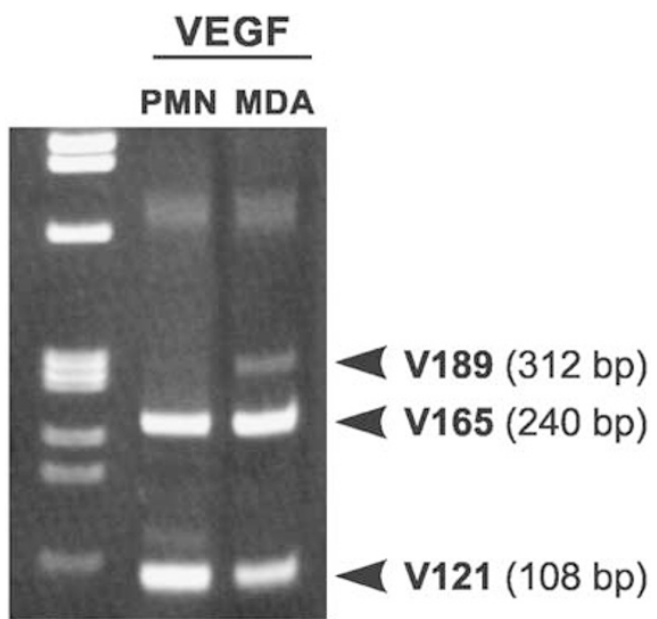

Figure 6 VEGF mRNA expression in mature PMN. Total RNA was extracted from highly purified PMN. After reverse transcription, PCR was carried out with specific primers for VEGF. The figure indicates the size of amplification products relative to molecular weight standards run in parallel. Major VEGF transcripts migrated at 240 and $108 \mathrm{bp}$, corresponding to V165 and V121, respectively; a weakly amplified transcript migrated at $312 \mathrm{bp}$, corresponding to V189 (line PMN). A breast cancer cell line (MDA-MB 231) served as control.

\section{Discussion}

As a tissue that undergoes rapid cyclic changes, the human endometrium is a good model for the study of physiological angiogenesis, which is under the control of ovarian hormones, estradiol and progesterone. We have previously shown that estradiol increases the expression of all VEGF isoforms, while progesterone increases specifically endometrial expression of V189 during the secretory phase. ${ }^{22}$ The secretion of native V189 by decidual cells of the secretory and pregnant endometrium was associated with an increase in vascular permeability. In the present study, we show for the first time that the V189 isoform can trigger PMN migration (chemotaxis and transmigration). Moreover, we obtained evidence that PMN can release their stock of V189 and thereby amplify this response.

V165 is chemotactic for monocytes, endothelial cells and some $\mathrm{T}$ cells. ${ }^{27,29,42}$ Our data show that VEGF also increases both random PMN migration under agarose (chemokinesis) and directed PMN migration (chemotaxis). This effect depended on the isoform. Native V189 was most active in both assays, while V165 was only active in the agarose assay. Our results extend recent data showing that V165, together with IL-8 or complement fraction C5a, induces PMN chemotaxis in vitro. ${ }^{43}$

VEGF specifically binds to two receptor-tyrosine kinases, Flt-1/ VEGF-R1 and KDR/ VEGF-R2 tyrosine kinase. The signaling pathway involved in V165-induced cell migration depends on the cell type. In early studies, Flt-1 was implicated in VEGFinduced migration of endothelial cells, ${ }^{9,44}$ although $\mathrm{KDR}$ is now considered to be the main receptor

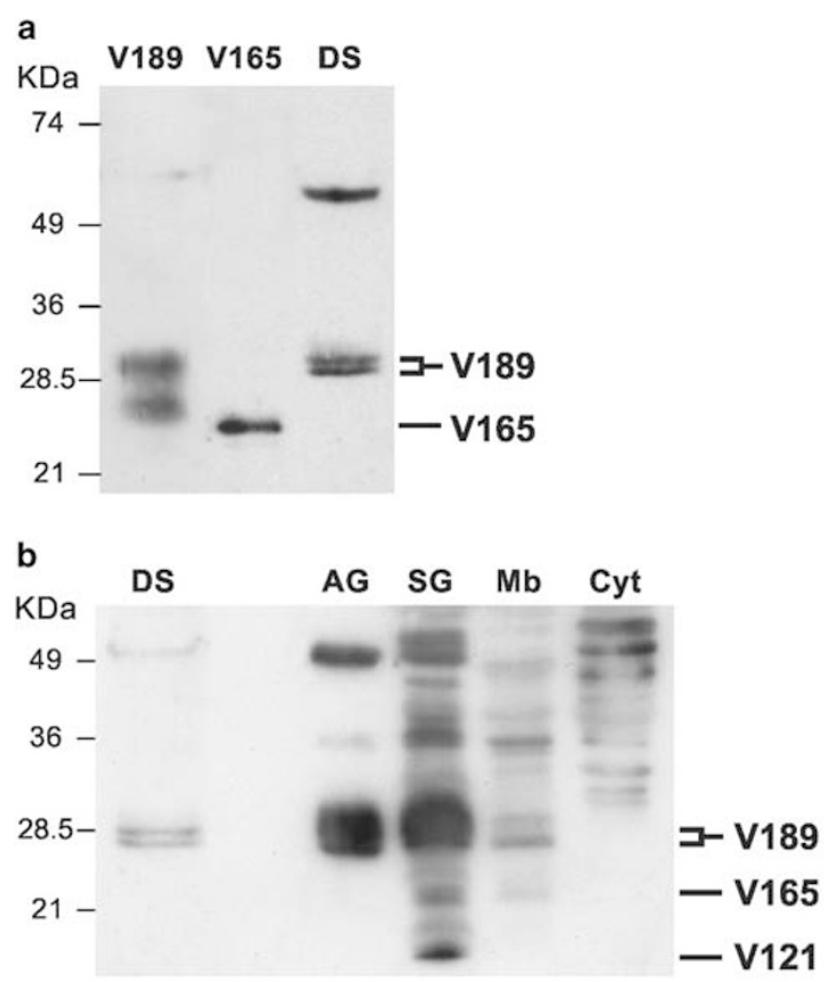

Figure 7 Degranulation of VEGF from human PMN and from isolated subcellular compartments. (a) Isolated PMN were submitted to degranulation treatment with cytochalasin and fMLP, and proteins in the supernatant (DS) were analyzed by Western blot in denaturing conditions, using a polyclonal antiVEGF antibody; recombinant V189 (50 ng) and V165 (75 ng), migrating at $28-30 \mathrm{kDa}$ and $24 \mathrm{kDa}$, respectively, were used as controls. The 52-kDa band in (a) and (b) probably corresponds to V189 dimers. (b) Specific $(S G)$ and azurophilic $(A G)$ granules were prepared on Percoll gradients, and proteins in these fractions were analyzed by Western blot in denaturing conditions. $D S$, degranulation supernatant control; $M b$, membrane fraction; Cyt, cytosolic fraction. No bands corresponding to V121, V165 or V189 monomers were detected in the cytosolic fraction.

involved in endothelial cell migration. ${ }^{45,46}$ V165 induces migration of human monocytes through Flt-1. ${ }^{27,28}$ Adult leukemia $\mathrm{T}$ cells also upregulate their own chemotaxis to facilitate their invasion of various organs, and a mechanism involving Flt-1 has been implicated in this process. ${ }^{29}$ More recently, activation of Flt-1 was reported to be necessary for in vivo recruitment of hematopoietic stem cell progenitors. ${ }^{47}$ Our experiments using various approaches show that human PMN significantly express Flt-1, and that Flt-1 is involved in VEGFinduced chemotaxis of PMN, similarly to VEGFinduced migration of monocytes.

Our results further show that V189-induced PMN migration on fibronectin is dependent on $\beta 1$-integrin. First, VEGF-induced transmigration was more efficient on fibronectin (a ligand of $\beta 1$-integrin) than on vitronectin and was strongly decreased by a blocking anti- $\beta 1$-antibody. Second, VEGF, and particularly V189, increases the expression of $\beta 1$-integrin at the PMN surface, using flow cytometric analysis; 

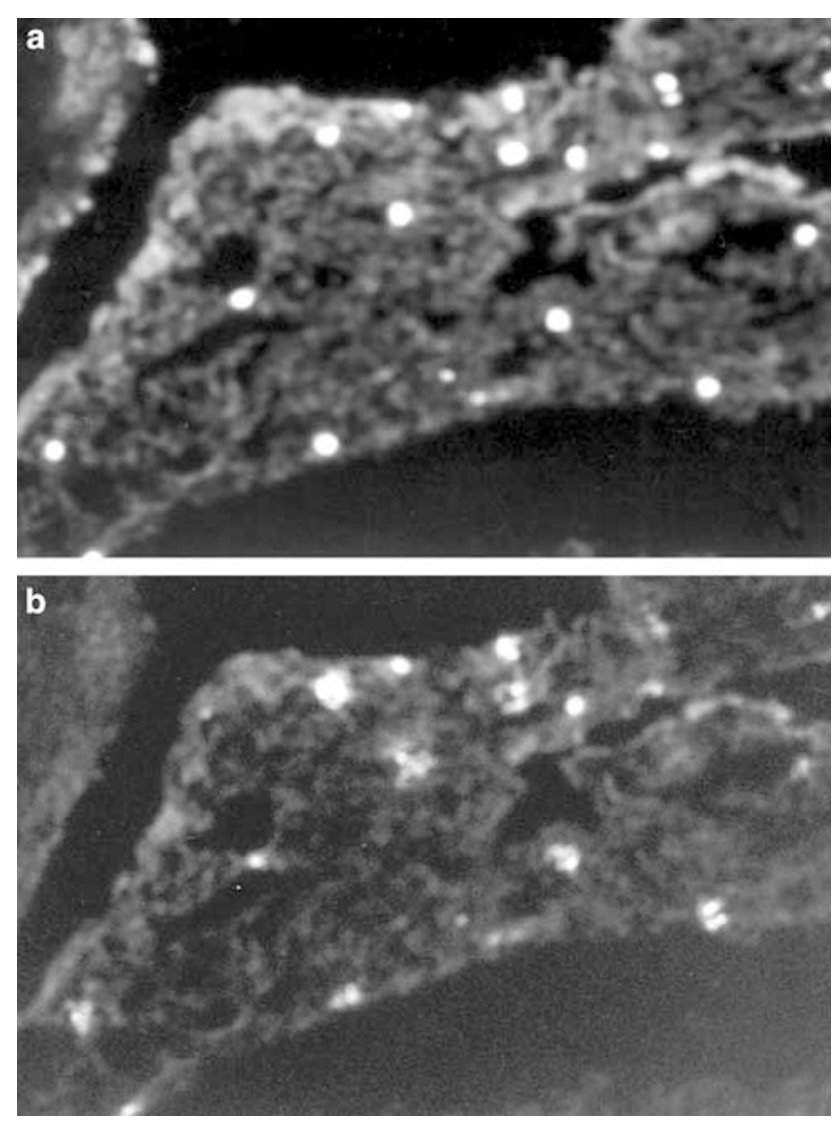

Figure 8 In situ VEGF expression by PMN. Sections of premenstrual human endometrium (day 28) were immunostained with both anti-CD-15 (a) and anti-VEGF (b). Note in (b) the strong VEGF immunolabeling of CD15-positive cells in inflammatory regions. Magnification $\times 400$.

these experiments were performed in whole-blood conditions known to prevent cell activation, as we previously reported. ${ }^{31}$ These observations are in keeping with previous reports that PMN migration is associated with upregulation of $\beta 1$-integrins both in vitro ${ }^{48,49}$ and in vivo. ${ }^{49,50}$ Expression of the heterodimers $\alpha_{2} \beta_{1^{-}}, \alpha_{4} \beta_{1^{-}}, \alpha_{5} \beta_{1^{-}}$and $\alpha_{6} \beta_{1^{-}}$integrins on these cells has previously been reported ${ }^{48,50,51}$ and implicated in PMN locomotion on collagen $\left(\alpha_{2} \beta_{1}\right.$ or VLA-2) ${ }^{49}$ and in extravasation on laminin 10 $(\alpha 6 \beta 1){ }^{35}$

Adhesion of leukocytes to the extracellular matrix is essential for their extravasation from blood vessels and subsequent migration to the stroma of inflamed tissues. Our data demonstrate that VEGF does not increase PMN adhesion to fibronectin, vitronectin or type IV collagen, suggesting that VEGF-induced migration on fibronectin might not be due to increased PMN adhesion to the extracellular matrix. The moderate upregulation on V189-treated PMN of CD11b and PECAM that mediates firm PMN adhesion to vascular endothelium and transmigration, respectively, and their weak CD62-L shedding that mediates rolling, further suggest that these three adhesion molecules are not essential for
VEGF-induced PMN migration. These data are in agreement with another study using fMLP as chemoattractant ${ }^{35}$ However, a contribution of $\beta 2$-integrins to $\beta 1$-integrin expression cannot be ruled out. ${ }^{52}$

Numerous studies have shown that human PMN mainly express and release the V165 isoform. ${ }^{6-8,53}$ Here, we re-examined the nature of the VEGF isoform(s) expressed by PMN, by using two different approaches: RT-PCR and Western blot of PMN degranulation supernatants. We found that PMN expressed V121 and V165 as the major mRNA, while V189 was more weakly expressed, in agreement with previous results. ${ }^{8}$ Interestingly, analysis of degranulation supernatants showed a band comigrating with human recombinant V189 protein, suggesting that this isoform shows the strongest protein expression in PMN. V189 is mainly stored in specific granules, as previously reported for V165 and $\mathrm{V} 121 ;^{6,7}$ the presence of V189 in azurophilic granules (and, to a lesser extent, in the membrane fraction) but not in the cytoplasm extends previous data. ${ }^{7}$ Thus, human PMN can synthesize and secrete all VEGF isoforms, in addition to other angiogenic peptides such as IL-8, ${ }^{54,55} \mathrm{TNF}^{56}$ and $\mathrm{HGF}^{32}$ suggesting a new role for PMN in angiogenesis.

As VEGF is one of the most potent known vascular permeability agents, and as microvascular hyperpermeability precedes and/or accompanies angiogenesis $^{1,2}$ in settings associated with massive PMN infiltration, it is tempting to speculate that VEGF released by PMN could play a role in the control of vascular permeability during inflammatory processes, such as a rabbit model of edema, ${ }^{57}$ peritoneal diseases, rheumatoid arthritis and psoriasis. ${ }^{58-60}$ Furthermore, the chemoattractant properties of PMN-secreted VEGF for monocytes ${ }^{27}$ may reinforce the monocyte recruitment to sites of acute inflammation, following the initial influx of PMN.

Menstruation represents an inflammatory process within the human endometrium, with an influx of neutrophils in the menstrual phase or following progesterone withdrawal, in areas of tissue breakdown. ${ }^{23,61,62}$ We have also previously observed V189 secretion by perivascular decidual endometrial cells during the mid-late secretory phase of the menstrual cycle. $^{22}$ Taken together, our findings support the view that V189 secreted by predecidual endometrial cells could attract neutrophils to specific areas of the human endometrium during the late secretory period corresponding to progesterone withdrawal. ${ }^{22}$ VEGF165 also induces IL-8 production by microvascular endothelial cells, eliciting PMN transendothelial migration. ${ }^{30}$ Moreover, VEGF produced by local PMN (this study, Gargett et $a l^{25}$ and Muller et $a^{l^{63}}$ ) could enhance PMN influx in an autocrine fashion, participate in monocyte recruitment, and increase vascular permeability during the inflammatory process associated with menstruation. ${ }^{59}$ Neutrophil-derived elastase and other proteinases, secreted together with VEGF, could facilitate degradation of vascular basement membranes and of the 
subendothelial matrix, also contributing to the menstruation. ${ }^{62-64}$ As anti-inflammatory drugs block numerous PMN secretions, ${ }^{31,34}$ including proteases and cytokines secretion, the therapeutic effect of nonsteroidal anti-inflammatory drugs in abnormal uterine bleeding ${ }^{65}$ could be explained by the roles of PMN in human endometrium remodeling.

In conclusion, our results demonstrate for the first time that the expression of the V189 isoform, which is selectively increased in perivascular decidual endometrial cells during the mid-late secretory phase of the menstrual cycle, participates in the observed PMN influx. Indeed, V189 was both chemotactic and chemokinetic for PMN in vitro, through a mechanism mainly involving $\beta 1$-integrinfibronectin interactions. We also obtained evidence that V189 could be locally released by PMN, pointing to a new autocrine regulatory loop and suggesting another link between inflammation and angiogenesis, via VEGF and PMN.

\section{Acknowledgements}

We thank Jean Plouët and Marc Trombe (CNRS, Toulouse, France) for providing recombinant V189, Phil Thorpe for providing 2c3 antibody. This work was supported by Institut National de la Santé et de la Recherche Médicale, Centre National de la Recherche Scientifique, Association pour la Recherche sur le Cancer and Fondation pour la Recherche Médicale.

\section{References}

1 Dvorak HF, Brown LF, Detmar M, et al. Vascular permeability factor/vascular endothelial growth factor, microvascular hyperpermeability, and angiogenesis. Am J Pathol 1995;146:1029-1039.

2 Ferrara N, Davis-Smyth T. The biology of vascular endothelial growth factor. Endocr Rev 1997;18:4-25.

3 Neufeld G, Cohen T, Gengrinovitch S, et al. Vascular endothelial growth factor (VEGF) and its receptors. FASEB J 1999;13:9-22.

4 Sunderkotter C, Steinbrink K, Goebeler M, et al. Macrophages and angiogenesis. J Leukoc Biol 1994;55: 410-422.

5 Freeman MR, Schneck FX, Gagnon ML, et al. Peripheral blood T-lymphocytes and lymphocytes infiltrating human cancers express vascular endothelial growth factor: a potential role for $\mathrm{T}$ cells in angiogenesis. Cancer Res 1995;55:4140-4145.

6 Taichman NS, Young S, Cruchley AT, et al. Human neutrophils secrete vascular endothelial growth factor. J Leukoc Biol 1997;62:397-400.

7 Gaudry M, Bregerie O, Andrieu V, et al. Intracellular pool of vascular endothelial growth factor in human neutrophils. Blood 1997;90:4153-4161.

8 Webb NJ, Myers CR, Watson CJ, et al. Activated human neutrophils express vascular endothelial growth factor (VEGF). Cytokine 1998;10:254-257.

9 Waltenberger J, Claesson-Welsh L, Siegbahn A, et al. Different signal transduction properties of KDR and
Flt1, two receptors for vascular endothelial growth factor. J Biol Chem 1994;269:26988-26995.

10 Gitay-Goren H, Soker S, Vlodavsky I, et al. The binding of vascular endothelial growth factor to its receptors is dependent on cell surface-associated heparin-like molecules. J Biol Chem 1992;267:6093-6098.

11 Park J, Keller GA, Ferrara N. The vascular endothelial growth factor (VEGF) isoforms : differential deposition into the subepithelial extracellular matrix and bioactivity of extracellular matrix-bound VEGF. Mol Biol Cell 1993;4:1317-1326.

12 Houck KA, Leung DW, Rowland AM, et al. Dual regulation of vascular endothelial growth factor bioavailability by genetic and proteolytic mechanisms. J Biol Chem 1992;267:26031-26037.

13 Plouët J, Moro F, Bertagnolli S, et al. Extracellular cleavage of the vascular endothelial growth factor 189amino acid form by urokinase is required for its mitogenic effect. J Biol Chem 1997;272:13390-13396.

14 Cheng SY, Nagane M, Huang HJS, et al. Intracerebral tumor-associated hemorrhage caused by overexpression of the vascular endothelial growth factor isoforms VEGF121 and VEGF165 but not VEGF189. Proc Natl Acad Sci USA 1997;94:12081-12087.

15 Grunstein J, Masbad JJ, Hickey R, et al. Isoforms of vascular endothelial growth factor act in a coordinate fashion to recruit and expand tumor vasculature. Mol Cell Biol 2000;20:7282-7291.

16 Perrot-Applanat M. Hormonal regulation of vascular cell function. In: Bikfalvi A (ed). Encyclopedic Reference of Vascular Biology and Pathology. Springer Verlag: Berlin, 2000, PP. 157-162.

17 Torry DS, Holt VJ, Keenan JA, et al. Vascular endothelial growth factor expression in cycling human endometrium. Fertil Steril 1996;66:72-80.

18 Shifren JL, Tseng JF, Zaloudek CJ, et al. Ovarian steroid regulation of vascular endothelial growth factor in the human endometrium: implications for angiogenesis during the menstrual cycle and in the pathogenesis of endometriosis. J Clin Endocrinol Metab 1996;81: 3112-3118.

19 Bausero P, Cavaillé F, Meduri G, et al. Paracrine action of vascular endothelial growth factor in the human endometrium: production and target sites, and hormonal regulation. Angiogenesis 1998;2:167-182.

20 Zhang L, Rees MC, Bicknell R. The isolation and longterm culture of normal human endometrial epithelium and stroma. Expression of mRNAs for angiogenic polypeptides basally and on oestrogen and progesterone challenges. J Cell Sci 1995;108:323-331.

21 Hyder M, Stancel GM, Chiappetta C, et al. Uterine expression of vascular endothelial growth factor is increased by estradiol and tamoxifen. Cancer Res 1996;56:3954-3960.

22 Ancelin M, Buteau-Lozano H, Meduri G, et al. A dynamic shift of VEGF isoforms with a transient and selective progesterone-induced expression of VEGF189 regulates angiogenesis and vascular permeability in human uterus. Proc Natl Acad Sci USA 2002;99:6023-6028.

23 Poropatich C, Rojas M, Silverberg SG. Polymorphonuclear leukocytes in the endometrium during the normal menstrual cycle. Int J Gynecol Pathol 1987;6: 230-234.

24 Critchley HO, Kelly RW, Lea RG, et al. Sex steroid regulation of leukocyte traffic in human decidua. Hum Reprod 1996;11:2257-2262. 
25 Gargett CE, Lederman F, Heryanto B, et al. Focal vascular endothelial growth factor correlates with angiogenesis in human endometrium. Role of intravascular neutrophils. Hum Reprod 2001;16: 1065-1075.

26 King A, Welling V, Gardner L, et al. Immunocytochemical characterization of the unusual large granular lymphocytes in human endometrium throughout the menstrual cycle. Hum Immunol 1989;24:195-205.

27 Barleon B, Sozzani S, Zhou D, et al. Migration of human monocytes in response to vascular endothelial growth factor (VEGF) is mediated via the VEGF receptor flt-1. Blood 1996;87:3336-3343.

28 Clauss $M$, Weich $\mathrm{H}$, Breier $\mathrm{G}$, et al. The vascular endothelial growth factor receptor Flt-1 mediates biological activities. Implications for a functional role of placenta growth factor in monocyte activation and chemotaxis. J Biol Chem 1996;271:17629-17634.

29 Hayashibara T, Yamada Y, Miyanishi T, et al. Vascular endothelial growth factor and cellular chemotaxis; a possible autocrine pathway in adult T-cell leukemia cell invasion. Clin Cancer Res 2001;7:2719-2726.

30 Lee TH, Avraham H, Lee SH, et al. Vascular endothelial growth factor modulates neutrophil transendothelial migration via up-regulation of interleukin-8 in human brain microvascular endothelial cells. J Biol Chem 2002;277:10445-10451.

31 Grenier A, Dehoux M, Boutten A, et al. Oncostatin M production and regulation by human polymorphonuclear neutrophils. Blood 1999;93:1413-1421.

32 Grenier A, Chollet-Martin S, Crestani B, et al. Presence of a mobilizable intracellular pool of hepatocyte growth factor in human polymorphonuclear neutrophils. Blood 2002;99:2997-3004.

33 Nelson RD, Quie PG, Simmons RL. Chemotaxis under agarose: a new and simple method for measuring chemotaxis and spontaneous migration of human polymorphonuclear leukocytes and monocytes. J Immunol 1975;115:1650-1656.

34 Vicioso MA, Garaud JJ, Réglier-Poupet $\mathrm{H}$, et al. Moderate inhibitory effect of interleukin-10 on human neutrophil and monocyte chemotaxis in vitro. Eur Cytokine Netw 1998;9:247-253.

35 Sixt M, Hallmann R, Wendler O, et al. Cell adhesion and migration properties of $\beta 2$-integrin negative polymorphonuclear granulocytes on defined extracellular matrix molecules. J Biol Chem 2001;276:18878-18887.

36 Harler MB, Wakshull E, Filardo EJ, et al. Promotion of neutrophil chemotaxis through differential regulation of beta 1 and beta 2 integrins. J Immunol 1999; 162:6792-6799.

37 Loike JD, Cao L, Budhu S, et al. Blockade of $\alpha 5 \beta 1$ integrins reverses the inhibitory effect of tenascin on chemotaxis of human monocytes and polymorphonuclear leukocytes through three-dimentional gels of extracellular matrix proteins. J Immunol 2001;166: 7534-7542.

38 Brekken RA, Overholser JP, Stastny VA, et al. Selective inhibition of vascular endothelial growth factor (VEGF) receptor 2 (KDR/Flk-1) activity by a monoclonal anti-VEGF antibody blocks tumor growth in mice. Cancer Res 2000;60:5117-5124.

39 Chollet-Martin S, Montravers P, Gibert C, et al. Subpopulation of hyperresponsive polymorphonuclear neutrophils in patients with adult respiratory distress syndrome. Role of cytokine production. Am Rev Respir Dis 1992;146:990-996.
40 Borregaard N, Heiple JM, Simons ER, Clark RA. Subcellular localization of the b-cytochrome component of the human neutrophil microbicidal oxidase: translocation during activation. J Cell Biol 1983;9: $52-61$.

41 Meduri G, Bausero P, Perrot-Applanat M. Expression of vascular endothelial growth factors in the human endometrium: modulation during the menstrual cycle. Biol Reprod 2000;62:439-447.

42 Clauss M, Gerlach M, Gerlach H, et al. Vascular permeability factor: a tumor-derived polypeptide that induces endothelial cell and monocyte procoagulant activity, and promotes monocyte migration. J Exp Med 1990;172:1535-1545.

43 Zhang H, Isseukutz AC. Growth factor regulation of neutrophil-endothelial cell interactions. J Leukoc Biol 2001;70:225-232.

44 Seetharam L, Gotoh N, Maru Y, et al. A unique signal transduction from FLT tyrosine kinase, a receptor for vascular endothelial growth factor VEGF. Oncogene 1995;10:135-147.

45 Gille H, Kowalski J, Li B, et al. Analysis of biological effects and signaling properties of Flt-1 (VEGFR-1) and KDR (VEGFR-2). J Biol Chem 2001;276: 3222-3230.

46 Koolwijk P, Peters E, Van der Vecht B, et al. Involvement of VEGFR-2 (kdr/flk-1) but not VEGFR-1 (flt-1) in VEGF-A and VEGF-C-induced tube formation by human microvascular endothelial cells in fibrin matrices in vitro. Angiogenesis 2001;4:53-60.

47 Hattori K, Heissig B, Wu Y, et al. Placental growth factor reconstitutes hematopoiesis by recruiting VEGFR1+ stem cells from bone-marrow microenvironment. Nature Med 2002;8:841-849.

48 Kubes P, Niu XF, Smith CW, et al. A novel beta 1-dependant adhesion pathway on neutrophiles: a mechanism invoked by dihydrocytochalasin B or endothelial transmigration. FASEB J 1995;9:1103-1111.

49 Werr J, Johansson J, Eriksson EE, et al. Integrin $\alpha_{2} \beta_{1}$ (VLA-2) is a principal receptor used by neutrophils for locomotion in extravascular tissue. Blood 2000;95:1804-1809.

50 Werr J, Xie X, Hedqvist $\mathrm{P}$, et al. $\beta_{1}$ integrins are critically involved in neutrophil locomotion in extravascular tissue in vivo. J Exp Med 1998;187: 2091-2096.

51 Reinhardt PH, Ward CA, Giles WR, et al. Emigrated rat neutrophils adhere to cardiac myocytes via $\alpha_{4}$ integrin. Circ Res 1997;81:196-201.

52 Werr J, Eriksson EE, Hedqvist P, et al. Engagement of $\beta_{2}$ integrins induces surface expression of $\beta_{1}$ integrin receptors in human neutrophils. J Leukoc Biol 2000; 68:553-560.

53 Scapini P, Calzetti F, Cassatella MA. On the detection of neutrophil-derived vascular endothelial growth factor (VEGF). J Immunol Methods 1999;232:121-129.

54 Koch AE, Polverini PJ, Kunkel SL, et al. Interleukin-8 as a macrophage-derived mediator of angiogenesis. Science 1992;258:1798-1801.

55 Ethuin F, Delarche C, Benslama S, et al. Interleukin-12 increases interleukin 8 production and release by polymorphonuclear neuutrophils. J Leukoc Biol 2001;70:439-443.

56 Dubravec DB, Spriggs DR, Mannick JA, et al. Circulating human peripheral blood granulocytes synthetize and secrete tumor necrosis factor $\alpha$. Proc Natl Acad Sci USA 1990;87:6758-6761. 
57 Wedmore CV, Williams TJ. Control of vascular permeability by polymorphonuclear leukocytes in inflammation. Nature 1981;289:646-650.

58 Detmar M, Brown L, Claffey K, et al. Overexpression of vascular permeability factor and its receptors in psoriasis. J Exp Med 1994;180:1141-1146.

59 Koch AE, Harlow LA, Haines GK, et al. Vascular endothelial growth factor. A cytokine modulating endothelial function in rheumatoid arthritis. J Immunol 1994;152:4149-4156.

60 Enomoto H, Inoki I, Komiya K, et al. Vascular endothelial growth factor isoforms and their receptors are expressed in human osteoarthritic cartilage. Am J Pathol 2003;162:171-181.
61 Finn C. Implantation, menstruation and inflammation. Biol Rev Camb Philos Soc 1986;61:313-328.

62 Lathbury LJ, Salamonsen LA. In vitro studies of the potential role of neutrophils in the process of menstruation. Mol Hum Reprod 2000;6:899-906.

63 Mueller MD, Lebovic DI, Garrett E, et al. Neutrophils infiltrating the endometrium express vascular endothelial growth factor: potential role in endometrial angiogenesis. Fertil Steril 2000;74:107-112.

64 Freitas S, Meduri G, Le Nestour E, et al. Expression of metalloproteinases and their inhibitors in blood vessels in human endometrium. Biol Reprod 1999;61:1070-1082.

65 Shaw RW. Assessment of medical treatment of menorrhagia. Br J Obstet Gynaecol 1994;101:15-18. 